Research Article

\title{
Partitioning of Forage Mass and Nutritive Value in Sunn Hemp Leaf and Stem Components
}

\author{
Isaac Lepcha $\mathbb{D}^{1}$ and Harley D. Naumann ${ }^{2}$ \\ ${ }^{1}$ Department of Agriculture, Geosciences, and Natural Resources, University of Tennessee at Martin, Martin, TN 38237, USA \\ ${ }^{2}$ Division of Plant Science, University of Missouri, Columbia, MO 65211, USA \\ Correspondence should be addressed to Isaac Lepcha; ilepcha1@utm.edu
}

Received 22 January 2021; Revised 3 May 2021; Accepted 11 August 2021; Published 18 August 2021

Academic Editor: Othmane Merah

Copyright (c) 2021 Isaac Lepcha and Harley D. Naumann. This is an open access article distributed under the Creative Commons Attribution License, which permits unrestricted use, distribution, and reproduction in any medium, provided the original work is properly cited.

\begin{abstract}
Sunn hemp (SH; Crotalaria juncea L.) is a fast-growing, annual, warm-season tropical legume that could complement less productive cool-season forages such as tall fescue during summer. Little is known about seasonal forage mass and nutritive value partitioning in SH plant components when $\mathrm{SH}$ is managed for forage. We determined partitioning of forage mass and nutritive value (crude protein (CP), in vitro true digestibility (IVTD), neutral detergent fiber (NDF), acid detergent fiber (ADF), and neutral detergent fiber digestibility (NDFD)) concentrations in SH leaves and stems harvested 35, 45, and 55 days after planting (DAP) at Bradford Research Center, Columbia, MO, in a 2-year field study. Leaf and stem mass increased with increasing DAP and was greatest $(P \leq 0.05)$ at $55 \mathrm{DAP}$ followed by 45 and $35 \mathrm{DAP}$. Stems contributed most to the total forage mass beyond $45 \mathrm{DAP}$. Across years, CP was greatest $(P \leq 0.05)$ in leaves $\left(281 \mathrm{~g} \mathrm{~kg}^{-1} \mathrm{DM}\right)$ and lowest for stems $\left(81 \mathrm{~g} \mathrm{~kg}^{-1} \mathrm{DM}\right)$ at 55 DAP. The lowest NDF $(P \leq 0.05)$ was observed in leaves $\left(251 \mathrm{~g} \mathrm{~kg}^{-1} \mathrm{DM}\right)$ and stems $\left(585 \mathrm{~g} \mathrm{~kg}^{-1} \mathrm{DM}\right)$ at $35 \mathrm{DAP}$. Acid detergent fiber was lowest $(P \leq 0.05)$ for SH leaves $\left(178 \mathrm{~g} \mathrm{~kg}^{-1} \mathrm{DM}\right)$ and stems $\left(484 \mathrm{~g} \mathrm{~kg}^{-1} \mathrm{DM}\right)$ at $35 \mathrm{DAP}$. Digestibility of leaves was greater than that of stems and generally decreased with maturity. The nutritive value of leaves was consistently greater than that of stems and decreased with maturity, except for CP of leaves, which was maintained throughout the season. Results suggested that SH leaves can maintain forage mass and greater quality than its stem throughout the growing season.
\end{abstract}

\section{Introduction}

The relative contribution of plant components (leaf and stem) to total plant dry matter are major determinants of nutritive value in forage crops [1]. As in grasses [2], it is also important to understand the relationships between dry matter and nutritive value partitioning of leaf and stem components in legumes for grazing management decisions. Knowledge such as this would help producers make decisions regarding integration of either cool- or warm-season forage types that could help meet the seasonal demand of grazing livestock. Such integration of warm-season forage legumes would be particularly important in temperate regions where cool-season forage species like tall fescue (TF; Schedonorus arundinaceus (Schreb.) Dumort., nom. cons.) become dormant during warm summer months [3-5].
Sunn hemp (SH; Crotalaria juncea L.) is one such warmseason annual legume widely grown in Southeast Asia and Brazil as a green manure crop and for manufacturing cordage and high-quality paper [6]. Sunn hemp is also well adapted to hot, wet, and humid conditions, requiring a minimum of $25 \mathrm{~mm}$ of moisture per week for rapid germination and early growth in marginal to well-drained soils of $\mathrm{pH}$ ranging from 5.0 to 8.4 [7-9]. In Southeast Asia, sunn hemp has been commonly cultivated in pure stands to be used both as a fresh forage and hay $[7,10,11]$. The interest in using $\mathrm{SH}$ as forage has been attributed to its ability to accumulate a large amount of biomass in a short period of time [12-14], and its sufficient nutritive value for providing highquality forage that meets nutritional requirements for cattle [15-18]. However, there is no known research on the use of sunn hemp as forage for cattle in feeding systems. The only 
TABLE 1: Planting, sample-collection periods, temperature, and accumulated growing degree days (GDD) during 2015 and 2016 growing seasons, Bradford Research Center, Missouri.

\begin{tabular}{|c|c|c|c|c|c|c|c|c|c|}
\hline \multicolumn{3}{|c|}{ Planting and sampling dates } & \multicolumn{4}{|c|}{ Years and temperature } & \multicolumn{3}{|c|}{ Years and GDD } \\
\hline \multirow{2}{*}{2015} & \multirow{2}{*}{2016} & \multirow{2}{*}{ Days } & \multicolumn{2}{|c|}{2015} & \multicolumn{2}{|c|}{2016} & \multirow{2}{*}{2015} & \multirow{2}{*}{2016} & \multirow{2}{*}{ Average } \\
\hline & & & Max. & Min. & Max. & Min. & & & \\
\hline 1: 30 July-3 Sept. & 1: 30 July-3 Sept. & 35 & 34.7 & 14.4 & 34.7 & 14.9 & 479.7 & 833.7 & 656.8 \\
\hline 2: 30 July-13 Sept. & 2: 30 July-13 Sept. & 45 & 32.0 & 10.7 & 34.0 & 13.2 & 601.5 & 1054.6 & 828.1 \\
\hline 3: 30 July-23 Sept. & 3: 30 July-23 Sept. & 55 & 33.4 & 7.0 & 33.5 & 8.6 & 700.0 & 1279.4 & 994.2 \\
\hline
\end{tabular}

$\dagger \mathrm{GDD}$ averaged across years. $\ddagger \mathrm{GDD}$ calculated as ((maximum temp. + minimum temp. $) / 2)-10^{\circ} \mathrm{C}$.

TABLE 2: Mean monthly precipitation records for June through September 2015 and 2016 growing seasons and 17-year (2000-2016) average precipitation.

\begin{tabular}{lccc}
\hline \multirow{2}{*}{ Month } & \multicolumn{3}{c}{ Precipitation $(\mathrm{mm}) \dagger$} \\
& 2015 & 2016 & 17 -year mean $\ddagger$ \\
\hline June & 129.5 & 28.7 & 126.4 \\
July & 203.7 & 274.1 & 94.5 \\
Aug. & 105.7 & 149.4 & 98.4 \\
Sept. & 21.1 & 142.5 & 78.8 \\
Total rainfall & 460.0 & 594.7 & 399.1 \\
\hline
\end{tabular}

$\dagger$ Bradford Research and Extension Center, Columbia, Missouri Mesonet Weather Data. $\$ 2000-2016$; data not available prior to 2000 .

study that gives some details on the use of sunn hemp as forage was by Balaraman and Vankaterishman [19] who determined that an average hay intake of rams was $2.57 \mathrm{~kg}$ DM per $100 \mathrm{~kg}$ body weight.

Although SH has high potential as a productive, highnutritive value forage when conventional forages such as tall fescue are unavailable during summer [20], it is not commonly grown for forage in the warm-temperate regions. Moreover, very little is known about the distribution of leaf dry matter and overall forage nutritive value of $\mathrm{SH}$ throughout the growing season under low-input systems in warm-temperate regions during summer. Studies of forage mass partitioning in SH have largely focused on fiber and nitrogen concentrations as a part of cover crop suitability studies $[12,16]$, rather than overall forage nutritive value. There is a need to develop a more comprehensive understanding of nutritive value partitioning to $\mathrm{SH}$ leaves and stem under low-input systems in warm-temperate regions for use in forage-livestock systems. A study such as this will thus provide a basis for assessing and determining the suitability of incorporating sunn hemp as forage in different feeding systems. We conducted a follow-up study to Lepcha et al. [20] (a whole plant forage study) focused on sunn hemp leaf and stem forage value. Our objective was to compare the effect of maturity on forage mass and nutritive value partitioning to leaves and stems of forage $\mathrm{SH}$ during the summer growing season.

\section{Materials and Methods}

2.1. Environmental Conditions. The study was conducted at Bradford Research Center, University of Missouri, Columbia, Missouri, USA $\left(38^{\circ} 53^{\prime} \mathrm{N} ; 92^{\circ} 12^{\prime} \mathrm{W}\right.$, elevation $271.3 \mathrm{~m}$ ), during the summer growing seasons (June-Sept.) of 2015 and 2016. Soil at the experimental site was a Mexico silt loam (fine, smectic, mesic, Aeric Vertic. Epiaquafs), characterized by poor drainage, 1 to $3 \%$ slope, and permeability ranging from 0.00 to $1.52 \mathrm{~mm} \mathrm{hr}^{-1}$ [21]. Soil test results indicated $\mathrm{pH} 6.3,4.2 \% \mathrm{OM}$, low (8 ppm phosphorus), medium (69 ppm K, $170 \mathrm{ppm} \mathrm{Mg}$ ), and high (2104 ppm Ca). The maximum and minimum temperature were $34.7^{\circ} \mathrm{C}$ and $7.0^{\circ} \mathrm{C}$ in 2015 and $35.2^{\circ} \mathrm{C}$ and $8.6^{\circ} \mathrm{C}$ in the 2016 experimental period (Table 1), respectively, indicating an overall cooler period in 2015 than in 2016. The rainfall distribution and amount varied within and between years (Table 2). Total rainfall from June through September (SH growing season) in 2015 and 2016 was 15.3 and $49.0 \%$ greater than the 17 -year average, respectively. The mean temperature for experimental periods 1 , 2, and 3 (Table 1) was 24.6, 21.4, and 20.2 in 2015 and 24.8, 23.6, and 21.1 in 2016, respectively. Growing degree days (GDD) was calculated as $\left[\left(T_{\max }+T_{\min }\right) / 2\right]-10^{\circ} \mathrm{C}$, where $T_{\max }$ and $T_{\min }$ are the daily maximum and minimum temperatures recorded, respectively. The base temperature $\left(10^{\circ} \mathrm{C}\right)$ in the calculation was used following Balkcom et al.'s study [22] for growth of SH. The number of GDD accumulated at each harvest averaged 480, 602, and 700 in 2015 and 834, 1055, and 1279 in 2016 (Table 1).

2.2. Experimental Design and Planting. A split-plot design with six replications was implemented in which three harvest regimes $(35,45$, and 55 days after planting (DAP)) were considered as the main plot and the two plant components (leaf and stem) as subplots. Forage accumulation, CP, NDF, ADF, IVTD, and NDFD over DAP were tested on plant components. The experiment was established in plots measuring 3 by $24 \mathrm{~m}$ during the summers of 2015 and 2016 with new planting and randomization plan each year. A disc harrow, typical of a conventional tillage practice, was implemented to prepare the experimental fields. In order to evaluate adaptation of SH to local environmental conditions under low-input systems, supplemental fertilizer, irrigation, or weed control measures were not applied in either year. Due to incessant rainfall and poor germination conditions in June, the planting date in 2015 occurred on July 30 and the same date was chosen in 2016 for uniformity. A commercial legume seed inoculant (Molokai Seed Company, Hawaii, USA) that contained Bradyrhizobium sp. (Vigna) was used to inoculate forage-type SH cultivar "Tropic Sun" seeds. Seeds at the rate of $22.5 \mathrm{~kg} \mathrm{ha}^{-1}$ were 
TABle 3: Probability of $P>F$ (type III sums of squares) from the analysis of variance among growing degree days (GDD) for yield, crude protein (CP), neutral detergent fiber (NDF), acid detergent fiber (ADF), in vitro true digestibility (IVTD), and neutral detergent fiber digestibility (NDFD) at three harvest intervals in Bradford Research Center, Missouri, during 2015.

\begin{tabular}{|c|c|c|c|c|c|c|c|c|c|c|c|c|}
\hline \multirow{3}{*}{ Effects } & \multicolumn{12}{|c|}{ Variables } \\
\hline & \multicolumn{2}{|c|}{ Yield } & \multicolumn{2}{|c|}{$\mathrm{CP}$} & \multicolumn{2}{|c|}{$\mathrm{NDF}$} & \multicolumn{2}{|c|}{$\mathrm{ADF}$} & \multicolumn{2}{|c|}{ IVTD } & \multicolumn{2}{|c|}{ NDFD } \\
\hline & Leaf & Stem & Leaf & Stem & Leaf & Stem & Leaf & Stem & Leaf & Stem & Leaf & Stem \\
\hline GDD & $<0.0001$ & $<0.0001$ & $<0.0001$ & $<0.0001$ & $<0.0001$ & $<0.0001$ & $<0.0001$ & $<0.0001$ & 0.0282 & $<0.0001$ & 0.9252 & $<0.0001$ \\
\hline
\end{tabular}

drilled using a no-till drill (Flex-II; Truax Company, Inc., $\mathrm{MN}, \mathrm{USA}$ ) approximately at a depth of $2.5 \mathrm{~cm}$ and $0.20 \mathrm{~m}$ row spacing.

2.3. Harvest Scheduling and Sampling. Total forage accumulation is defined as the sum of leaf and stem masses per unit area collected at a specific time (Table 3). Biomass samples for forage accumulation and forage nutritive value determination were collected at 35,45 , and 55 days after planting (DAP). All plant samples were randomly selected from interior $1 \mathrm{~m}^{2}$ areas and clipped approximately $10 \mathrm{~cm}$ above the ground from individual plots. In order to eliminate border effects, sampling within $0.5 \mathrm{~m}$ of the edges of each plot was avoided. Samples at each sampling date and from each plot were collected from separate locations. Plants were handseparated into leaves and stems (hereafter referred to as "component"), and fresh weights of all samples were immediately taken after the harvest and oven-dried at $60^{\circ} \mathrm{C}$ for $4 \mathrm{~d}$ and weighed back to determine dry matter (DM). Dried samples were ground to pass a $1.0 \mathrm{~mm}$ screen using a Wiley cutting mill for laboratory DM determination. Ground samples were used for subsequent laboratory analysis.

2.4. Laboratory Analysis. Laboratory DM content (\%) on all ground forage samples for each sampling date was determined following the procedures outlined by Undersander et al. [23]. All nutritive value analyses of CP, NDF, ADF, IVTD, and NDFD were conducted following the procedure described by Lepcha et al. [20] The neutral detergent fiber digestibility (NDFD; $48 \mathrm{hrs)}$ was calculated according to Mertens [24]. Lab DM (\%) was used to calculate final measures of nutritive content as determined by ANKOM Technology Corp. (Macedon, NY). All measures of nutritive content (DM, CP, NDF, ADF, IVTD, and NDFD) analyses were replicated.

2.5. Statistical Procedures. The data were analyzed as a splitplot arrangement using the GLIMMIX procedures of SAS version 9.4 [25]. Since a test of homogeneity of variance across years showed significant difference in residual variances for most response variables, results were presented by year. In order to relate growth-time response on plant development (leaf and stem dependent variables), corresponding growing degree days (GDD) to harvest regime (DAP) were utilized. Regression procedures using PROC REG of SAS were utilized to relate growing degree days (GDD) to all dependent variables of each component (forage accumulation, CP, NDF, ADF, IVTD, and NDFD), and the simplest best-fit linear regression trends were determined. Posttest comparisons of the means were conducted using the LSMEANS statement. All treatment differences were considered significant if $P \leq 0.05$.

\section{Results and Discussion}

3.1. Forage Accumulation. There was a significant $(P<0.01)$ variation among GDD for SH forage accumulation in both the years (Tables 3 and 4). Forage accumulation for both components (for leaf and stem) increased linearly with increasing GDD in both years accounting for 93 and $91 \%$ of the variations due to GDD in 2015 and 99 and 69\% in 2016, respectively (Figures 1(a) and 1(b)). The mean forage growth rate across harvest intervals was greater in 2016 than in 2015 (Table 5). These response differences in forage mass partitioning between the two years were due to differences in growth stages as a result of differences in GDD. As the crop biomass increases, the leaf-stem ratio generally decreases [26]. Therefore, it is likely that greater GDD accumulated in 2016 (Table 1) promoted accelerated growth accumulating a lower leaf-stem ratio than in 2015.

The leaf mass accumulation increased at the rate of $3.82 \mathrm{~kg} \mathrm{DM} \mathrm{GDD}^{-1}$ in 2015 corresponding to GDD ranging from 500 to 700 and $0.84 \mathrm{~kg} \mathrm{DM} \mathrm{GDD}^{-1}$ in 2016 corresponding to GDD ranging from 800 to 1300 (Figures 1(a) and $1(\mathrm{~b}))$. Moreover, leaf mass accumulation tends to plateau beyond 800 GDD (Figure 1(b)), which illustrates that $\mathrm{SH}$ can maintain greater leaf mass with increasing harvest intervals. On the other hand, stem mass accumulation increased linearly at a greater rate than that of leaves as GDD increased in both years.

Across years, SH leaf mass accumulation ranged from 700 to $>2000 \mathrm{~kg} \mathrm{DM} \mathrm{ha}^{-1}$ and that of stem ranged from 300 to $>4000 \mathrm{~kg} \mathrm{DM} \mathrm{ha}^{-1}$ depending upon summer growing conditions. By comparison across years, a study by Lepcha et al. [20] on whole plant reported SH herbage accumulation that ranged from 702 to $1668 \mathrm{~kg} \mathrm{DM} \mathrm{ha}^{-1}$. The current results agree with those reported by Marshall et al. [27] who recorded 1700 and $2700 \mathrm{~kg} \mathrm{DM} \mathrm{ha}^{-1}$ of SH leaves and stems, respectively, at mid-flowering stage. Mansoer et al. [16] found that $\mathrm{SH}$ produced more leaf than stem DM during the first 21 DAP and stem DM increased faster than leaves following 42 DAP. Although not consistent between years, this trend was observed in 2015 (Figure 1(a)). Overall, SH plants partitioned more mass to stems than leaves with greater GDD as evident in 2016 (Figure 1(b)).

Several factors affect $\mathrm{SH}$ biomass or forage production: higher seeding rates ( 34 to $56 \mathrm{~kg} \mathrm{ha}^{-1}$ ) were recommended 
TABLE 4: Probability of $P>F$ (type III sums of squares) from the analysis of variance among growing degree days (GDD) for yield, crude protein $(\mathrm{CP})$, neutral detergent fiber (NDF), acid detergent fiber (ADF), in vitro true digestibility (IVTD), and neutral detergent fiber digestibility (NDFD) at three harvest intervals in Bradford Research Center, Missouri, during 2016.

\begin{tabular}{ccccccccccccccc}
\hline \multirow{2}{*}{ Effects } & \multicolumn{2}{c}{ Yield } & \multicolumn{2}{c}{ CP } & \multicolumn{3}{c}{ NDF } & \multicolumn{3}{c}{ ADF } & \multicolumn{3}{c}{ IVTD } & \multicolumn{2}{c}{ NDFD } \\
& Leaf & Stem & Leaf & Stem & Leaf & Stem & Leaf & Stem & Leaf & Stem & Leaf & Stem \\
\hline GDD & 0.0870 & 0.0047 & 0.0135 & $<0.0001$ & 0.1685 & $<0.0001$ & $<0.0001$ & 0.0068 & 0.0062 & $<0.0001$ & 0.0265 & $<0.0001$ \\
\hline
\end{tabular}

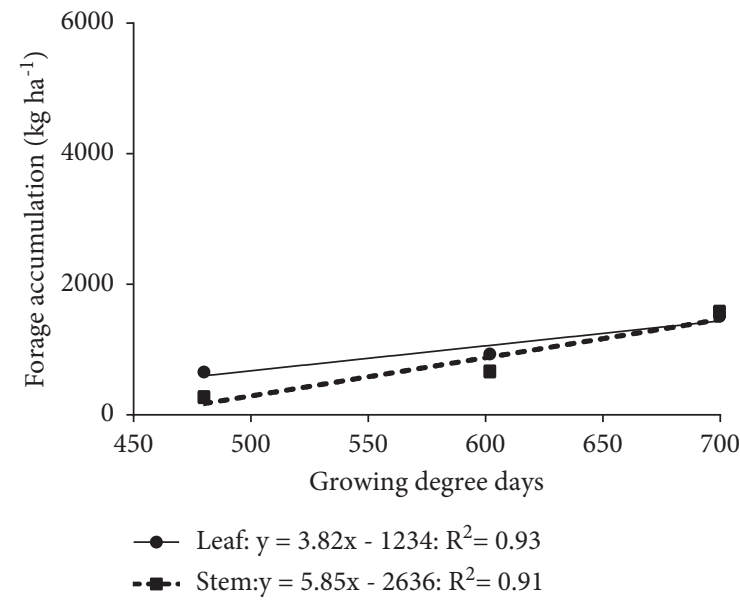

(a)

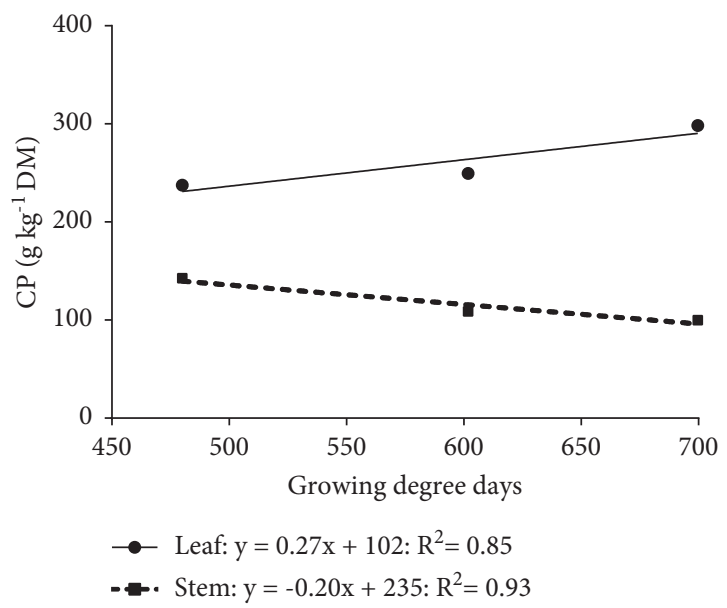

(c)

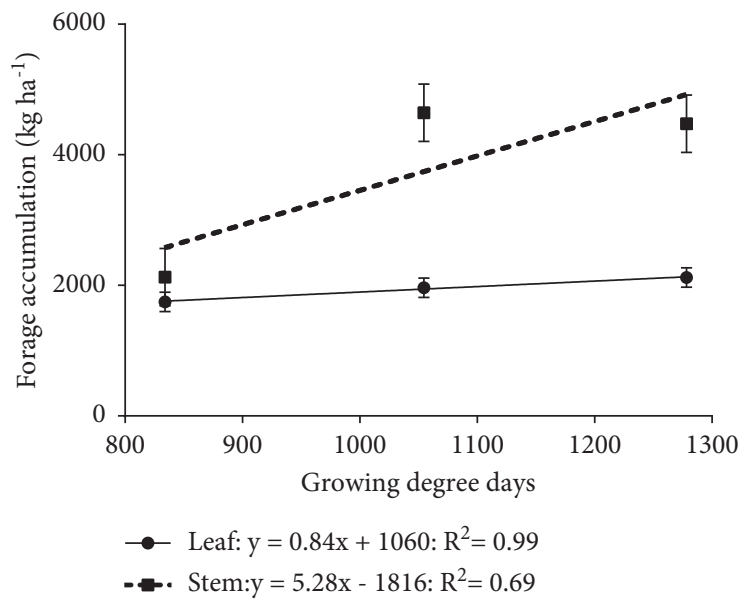

(b)

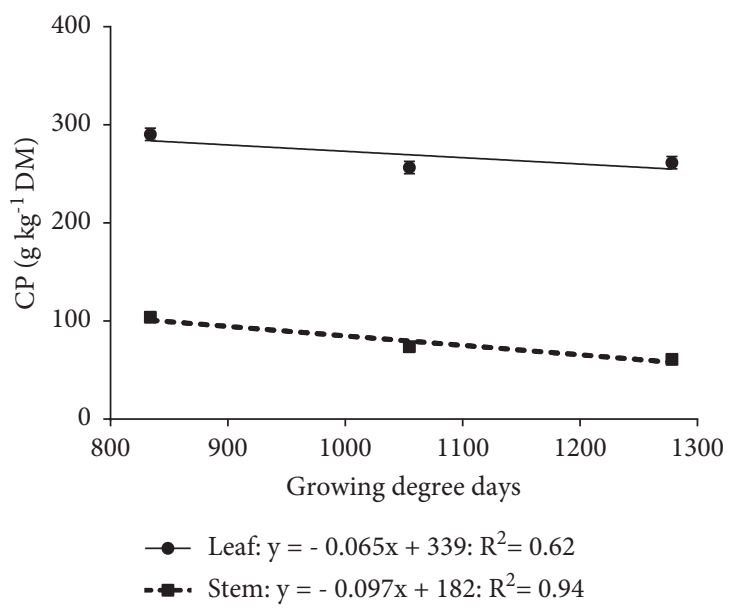

(d)

FIgURe 1: Predicted sunn hemp forage accumulation in (a) 2015 and (b) 2016 and crude protein (CP) in (c) 2015 and (d) 2016 in leaves and stems in response to average cumulative growing degree days (GDD) at Bradford Research Center, MO. Each point with error bars (SEM) corresponds to harvest intervals $(35,45$, and 55 days after planting) and their relationship to GDD.

for biomass or forage production [28]; early planting dates (June) at seeding rates of $17-34 \mathrm{~kg} \mathrm{ha}^{-1}$ [22]; fertilizer application, $\mathrm{K}$ and $\mathrm{S}$ at $40 \mathrm{~kg} \mathrm{ha}^{-1}$ [29]; length of growing period, 60-120 d [12]; and row spacing, $0.3 \mathrm{~m} \mathrm{[30].} \mathrm{However,}$ in our study, SH partitioned more mass to leaf when GDD ranged from around 500 to 700 and partitioned more mass to stem as GDD increased beyond 800 . It is apparent that $\mathrm{SH}$ leaf mass accumulation could be optimized from 800 to 1300 GDD, which corresponds to 35 to 55 DAP. This could also allow for a wider harvest window for producers to increase forage biomass by delaying harvest. While the amounts of leaf mass accumulation during early seasons were lower, amounts accumulated during late seasons increased linearly with increasing GDD, which also confirms the persistence of leaf mass over longer periods. Future research should therefore investigate the long-term effect of delayed harvesting for increased leaf biomass accumulation.

Leaf harvest of forages can provide a high-quality feed for livestock. In particular, this field operation could save time, energy, and expenditure by eliminating the need for hay equipment that is traditionally used to condition lowquality stems in the hay system. It is evident that the forage 
TABle 5: Mean forage leaf and stem mass and total forage accumulation and growth rates of sunn hemp during 2015 and 2016 growing seasons, Bradford Research Center, Missouri.

\begin{tabular}{|c|c|c|c|c|c|c|c|c|c|c|c|c|}
\hline \multirow{2}{*}{\multicolumn{2}{|c|}{ Leaf mass $\dagger$}} & & & $\mathrm{m}$ mas & & \multirow{2}{*}{\multicolumn{3}{|c|}{$\begin{array}{c}\text { Total forage } \\
\text { accumulation } \dagger\end{array}$}} & \multicolumn{3}{|c|}{ Forage growth rate $\dagger$} & Mean forage growth rate \\
\hline & & \multicolumn{4}{|c|}{ kg DM ha ${ }^{-1}$} & & & & \multicolumn{4}{|c|}{$\mathrm{kg} D M \mathrm{ha}^{-1} \mathrm{~d}^{-1}$} \\
\hline \multicolumn{13}{|c|}{ Days after planting } \\
\hline 35 & 45 & 55 & 35 & 45 & 55 & 35 & 45 & 55 & $0-35$ & $35-45$ & $45-5$ & \\
\hline \multicolumn{13}{|c|}{2015} \\
\hline 658 & 937 & 1513 & 272 & 667 & 1584 & 930 & $160 \overline{4}$ & 3096 & 27 & 67 & 149 & 81 \\
\hline \multicolumn{13}{|c|}{2016} \\
\hline 1751 & 1967 & 2125 & 2130 & 4653 & 4484 & 3881 & $662 \overline{0}$ & 6609 & 111 & 274 & -1 & 128 \\
\hline
\end{tabular}

$\dagger$ Average across samples.

leaf harvest of sunn hemp can provide a high-nutritive value feed. These leaves could be mixed with other feed ingredients that may provide an opportunity to develop different feeding scenarios. However, mechanical fractionation of sunn hemp leaves and stems could present technological challenges in the field. Therefore, the prospect of using a simple field stripping machine similar to the one used in alfalfa harvest fractionation [31] could be explored to separate sunn hemp leaves for their high nutritive content.

3.2. Crude Protein Concentration. In 2015, leaf CP concentrations increased linearly accounting for $85 \%$ of the variation due to GDD (Figure 1(c)). Lower GDD most likely slowed growth and nitrogen accumulation, and thus $\mathrm{CP}$ concentrations, during early growth stages of SH plants. Schomberg et al. [12] reported that SH biomass and nitrogen content increased with DAP and attributed lower GDD to slowed growth and increased nitrogen accumulation. Comparable results were reported in alfalfa wherein delayed maturity due to water stress increased $\mathrm{CP}$ concentrations [32]. Stem CP concentrations decreased linearly with increasing GDD (Figure 1(c)). In 2016, however, both leaf and stem CP concentrations decreased linearly accounting for 62 and $94 \%$ of the variations due to GDD (Figure 1(d)). Leaf CP concentrations increased at a greater rate $\left(0.27 \mathrm{~g} \mathrm{~kg} \mathrm{GDD}^{-1}\right)$ in 2015 and decreased in 2016 (Figures 1(c) and 1(d)). Stem $\mathrm{CP}$ concentrations decreased linearly with increasing GDD in both years (Figure 1(d)). As the crop biomass increases, the leaf-stem ratio generally decreases [33], and an increasingly greater amount of $\mathrm{C}$ and $\mathrm{N}$ is allocated to the stem [34]. Similar observations were made in Lucerne and ryegrass where a greater decrease in the $\mathrm{N}(\mathrm{CP})$ concentration of stems and the minimal decrease in $\mathrm{N}$ concentrations of leaves were associated with the decrease in leaf-stem ratio [26]. It is likely that greater GDD accelerated growth and hence biomass accumulation and that $\mathrm{CP}$ concentrations decreased with increased GDD.

Averaged across sampling dates, leaves and stems contributed $69\left(263 \mathrm{~g} \mathrm{CP} \mathrm{kg}^{-1} \mathrm{DM}\right)$ and $31 \%\left(117 \mathrm{~g} \mathrm{CP} \mathrm{kg}^{-1}\right.$ $\mathrm{DM})$, respectively, of the total CP in 2015 and $77(270 \mathrm{~g}$ $\left.\mathrm{CP} \mathrm{kg}{ }^{-1} \mathrm{DM}\right)$ and $23 \%\left(80 \mathrm{~g} \mathrm{CP} \mathrm{kg}^{-1} \mathrm{DM}\right)$, respectively, of the total CP in 2016. By comparison across years and sampling dates, a study by Lepcha et al. [20] reported that the $\mathrm{CP}$ concentration of whole plant SH ranged from 101 to
$178 \mathrm{~g} \mathrm{CP} \mathrm{kg}^{-1} \mathrm{DM}$. The current values were in agreement with that of Mansoer et al. [16] who reported 209 to $360 \mathrm{~g}$ $\mathrm{CP} \mathrm{kg}^{-1} \mathrm{DM}$ contributed by SH leaves when grown following summer corn harvest across years, locations, and maturity. However, the CP concentration of alfalfa (Medicago sativa L.) assessed across locations, years, and four cultivars ranged from 175 to $234 \mathrm{~g} \mathrm{~kg}^{-1}$ [35]. These values were lower than the values recorded in our study. Conversely, tall fescue, which is one of the most commonly used cool-season species, provided only $100 \mathrm{~g} \mathrm{CP} \mathrm{kg}^{-1} \mathrm{DM}$ during summer [3], a value far less than SH leaf CP concentrations. Average across years, the sunn hemp leaf CP concentration was $281 \mathrm{~g} \mathrm{~kg}^{-1} \mathrm{DM}$ at $55 \mathrm{DAP}$, which was greater than the CP concentrations $\left(155 \mathrm{~g} \mathrm{~kg}^{-1} \mathrm{DM}\right)$ of whole plant harvested at 35 DAP managed under similar conditions [20]. The amount of $\mathrm{CP}$ concentration is also in concurrent with the greatest amount of leaf mass at the same harvest date. These results have significant importance as producers can delay harvesting and can still maintain greater $\mathrm{CP}$ concentrations that may be necessary for late summer and early fall grazing animals. On the other hand, stem $\mathrm{CP}$ concentrations declined rapidly with plant maturity corresponding to increased GDD. According to Buxton [36] and NRC [37], CP requirements range from $70 \mathrm{~g} \mathrm{~kg}^{-1}$ for mature beef cows up to $190 \mathrm{~g} \mathrm{~kg}^{-1}$ for high-producing dairy cows. Although protein fractions associated with sunn hemp leaves and stems were not quantified, it is likely that the trend would follow reports by Solati et al. [38] and Hakl et al. [39]. This report suggested that $63-68 \%$ of the true protein in legume leaves is soluble and that stems account for greater nonprotein and indigestible nitrogen compared with leaves, respectively. By this measure, the sunn hemp leaf $\mathrm{CP}$ concentration would hold true for meeting requirements for different classes and sizes of cattle if supported by the measured forage intake of sunn hemp under different feeding systems. Future studies should investigate the forage intake of sunn hemp incorporated in different feeding systems.

3.3. Fiber Concentrations. Leaf and stem NDF concentrations increased linearly both years accounting for 78 and $98 \%$ of the variations due to GDD in 2015 and 52 and $92 \%$ of the variations due to GDD in 2016, respectively (Figures 2(a) and 2(b)). Leaf NDF concentrations increased at the rate of 0.35 and $0.05 \mathrm{~g} \mathrm{~kg}^{-1} \mathrm{GDD}^{-1}$ in 2015 


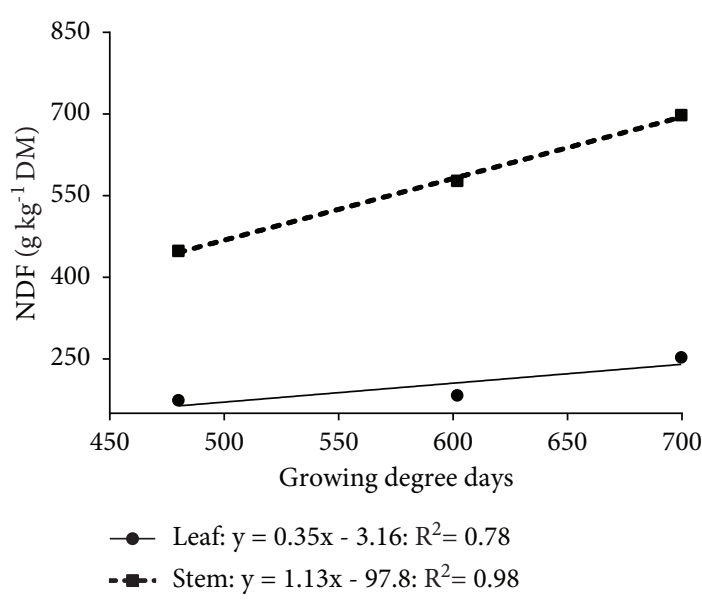

(a)

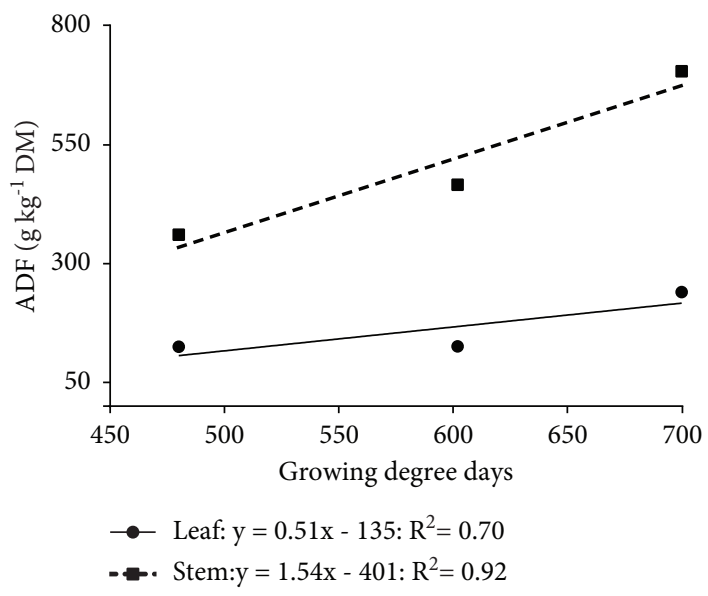

(c)

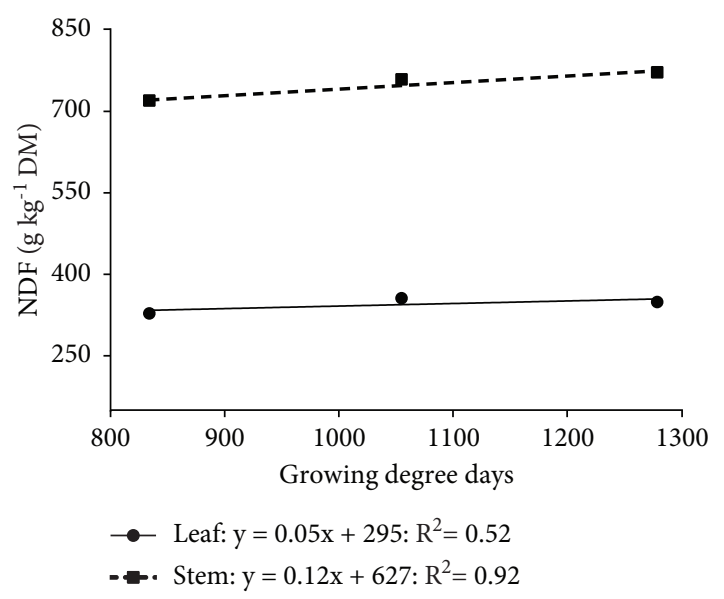

(b)

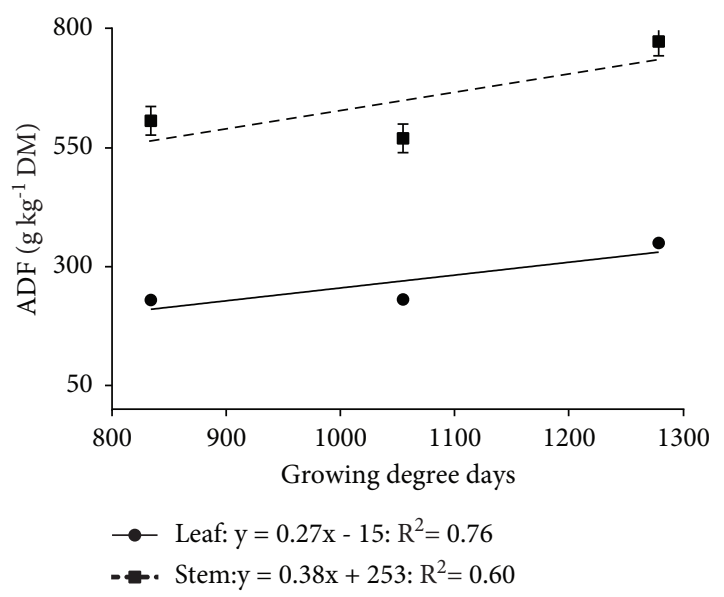

(d)

Figure 2: Predicted sunn hemp forage neutral detergent fiber (NDF) in (a) 2015 and (b) 2016 and acid detergent fiber (ADF) in (c) 2015 and (d) 2016 in the leaf and stem in response to average cumulative growing degree days (GDD) at Bradford Research Center, MO. Each point with error bars (SEM) corresponds to harvest intervals $(35,45$, and 55 days after planting) and their relationship to GDD.

and 2016, respectively. It was also observed that the variations due to GDD in leaf NDF concentrations were minimal $\left(R^{2}=0.52\right)$, specifically beyond 800 GDD in 2016 (Figure 2(b)). This is important for an annual legume that can maintain low leaf NDF concentrations with increased GDD throughout the summer growing season when coolseason forages become fibrous. Stem NDF concentrations increased at the rate of 1.13 and $0.12 \mathrm{~g} \mathrm{~kg}^{-1} \mathrm{GDD}^{-1}$ in 2015 and 2016, respectively (Figures 2(a) and 2(b)), approximately three times the rate of increase of leaf NDF. The stem NDF concentration was greatly correlated to GDD $\left(R^{2}=0.92\right.$ and 0.98$)$ in both years (Figures 2(a) and 2(b)). This variation in fiber concentration due to GDD is associated with the proportion of structural tissues (e.g., xylem and sclerenchyma) concentrated in the stem and leaves. The rate of plant development normally increases with high temperature and reduces the leaf-stem ratio [34]. With the increase in plant maturity, structural tissues proportion occupies larger portion of the stem than leaves, which is largely occupied by thin-walled mesophyll cells [40]. This structural tissues proportion occupies the cell wall representing the total fiber (NDF) concentration of plant and plant organs.

Leaf and stem ADF concentrations increased linearly in both years accounting for 70 and $92 \%$ of the variations due to GDD in 2015 and 76 and $60 \%$ of the variations due to GDD in 2016, respectively (Figures 2(a) and 2(d)). Like NDF concentrations, the rate of increase in stem ADF concentration was greater than the rate of increase in leaf $\mathrm{ADF}$ concentration in both years. Overall fiber concentrations increased with increased GDD (Figures 1(a)-1(d)).

Across years and sampling dates, leaf NDF concentrations ranged from 174 to $356 \mathrm{~g} \mathrm{~kg}^{-1} \mathrm{DM}$ and stem NDF ranged from 449 to $772 \mathrm{~g} \mathrm{~kg}^{-1} \mathrm{DM}$ (Figures 2(a) and 2(b)). Similarly, leaf ADF concentrations ranged from 125 to $350 \mathrm{~g} \mathrm{~kg}^{-1} \mathrm{DM}$ and stem ADF concentrations ranged from 361 to $774 \mathrm{~g} \mathrm{~kg}^{-1} \mathrm{DM}$ (Figures 2(c) and 2(d)). These results for leaf NDF concentrations were lower than the results reported by Mansoer et al. [16], where mean leaf NDF ranged from 244 to $373 \mathrm{~g} \mathrm{~kg}^{-1}$ and ADF from 189 to $289 \mathrm{~g} \mathrm{~kg}^{-1}$, and stem ADF ranged from 535 to 664 , for leaves harvested from 42 to 84 DAP. In 


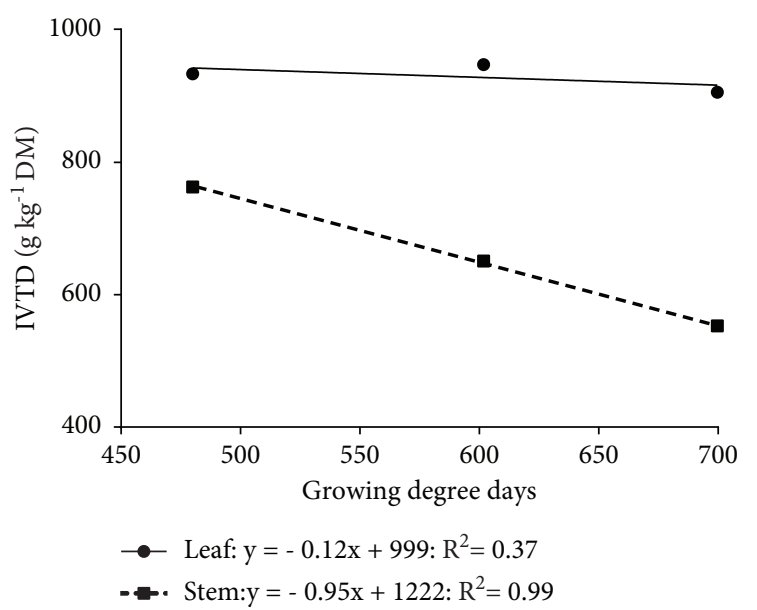

(a)

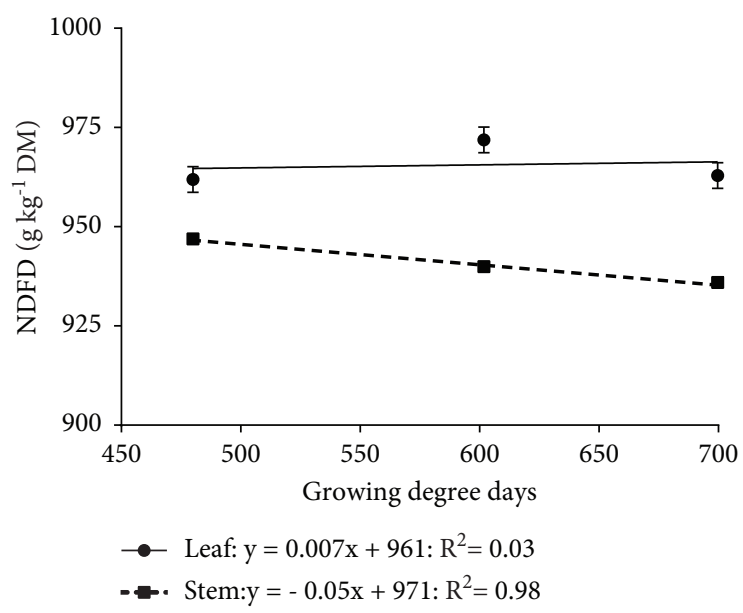

(c)

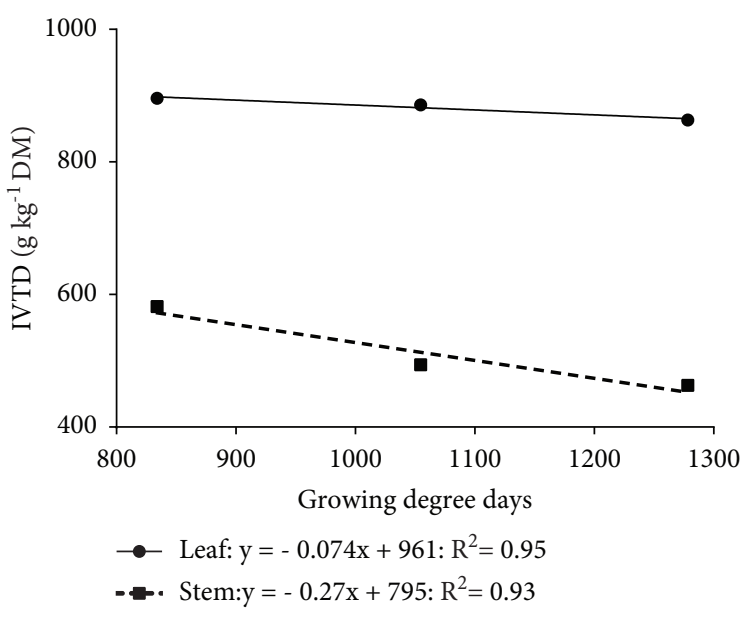

(b)

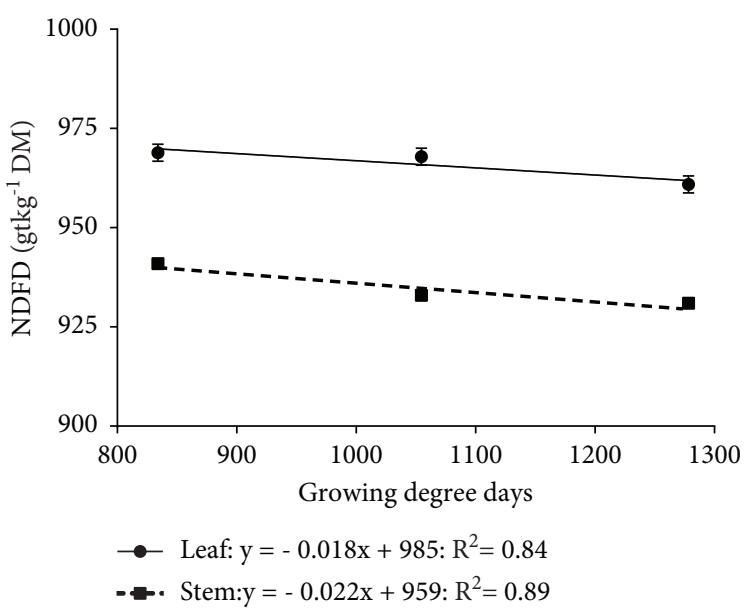

(d)

FIgure 3: Predicted sunn hemp forage in vitro true digestibility (IVTD) in (a) 2015 and (b) 2016 and NDF digestibility (NDFD) in (c) 2015 and (d) 2016 in the leaf and stem in response to average cumulative growing degree days (GDD) at Bradford Research Center, MO. Each point with error bars (SEM) corresponds to harvest intervals $(35,45$, and 55 days after planting) and their relationship to GDD.

comparison, NDF concentrations of whole plant $\mathrm{SH}$ ranged from 399 to $615 \mathrm{~g} \mathrm{~kg}^{-1} \mathrm{DM}$, and ADF concentrations ranged from 301 to $508 \mathrm{~g} \mathrm{~kg}^{-1} \mathrm{DM}$ across years and sampling dates [20].

Forage NDF is highly correlated with feed intake and rumen fill in cattle [41]. Since fiber is generally less fermentable than nonfibrous feed constituents such as starch and sugars, increased fiber content decreases fermentable energy [42]. For instance, maximum energy intake in early lactating cows occurs at NDF concentrations ranging from 25 to $35 \%$ of dry matter [42]. Similarly, in a balancing ration, a minimum of $25 \%$ NDF and $21 \% \mathrm{ADF}$ are recommended [17]. It has also been estimated that NDF concentrations ranging from 700 to $750 \mathrm{~g} \mathrm{NDF} \mathrm{kg}^{-1}$ $\mathrm{DM}$ at maximum in the diets of mature beef cows, and concentrations ranging from 150 to $200 \mathrm{~g} \mathrm{NDF} \mathrm{kg}^{-1} \mathrm{DM}$ at minimum in the diets of finishing ruminants will not hinder production or intake [36]. Similarly, the NDF concentration of about $270-290 \mathrm{~g} \mathrm{~kg}^{-1} \mathrm{DM}$ is considered optimum in diets of high-producing dairy cows at peak lactation for adequate energy and maintenance [43]. By comparison, alfalfa leaves at midflowering stage contained $250 \mathrm{~g} \mathrm{NDF} \mathrm{kg}^{-1} \mathrm{DM}$ and stems ranged from 450 to $750 \mathrm{~g} \mathrm{NDF} \mathrm{kg}^{-1} \mathrm{DM}$ from upper to lower canopy $[44,45]$. On the other hand, cool-season grasses like tall fescue during dormancy recorded mean NDF and ADF values of 548 and $321 \mathrm{~g} \mathrm{~kg}^{-1}$, respectively [46]. Based on the measure of plant components in this study, and considering that animals are more selective toward leaves than the stem, $\mathrm{SH}$ leaves maintained significantly lower fiber concentrations than that which may be considered optimum for different classes and sizes of grazing animals. Moreover, the whole plant fiber concentration at 35 DAP was greater [20] than the fiber concentrations obtained from leaves harvested at 45 and 55 DAP in the current study. These results have significant importance as producers can delay harvesting and can still maintain lower fiber concentrations that may be necessary for late summer and early fall grazing animals.

3.4. Forage Digestibility. Forage IVTD decreased linearly accounting for 37 and $99 \%$ of the variations due to GDD in 2015 and 95 and $93 \%$ of the variations due to GDD for the leaf and stem, respectively, in 2016 (Figures 3(a) and 3(b)). 
Leaf IVTD decreased at the rates of 0.12 and $0.074 \mathrm{~g} \mathrm{~kg}^{-1}$ $\mathrm{GDD}^{-1}$ in 2015 and 2016, respectively. Similarly, stem IVTD decreased at the rates of 0.95 and $0.27 \mathrm{~g} \mathrm{~kg}^{-1} \mathrm{GDD}^{-1}$ in 2015 and 2016, respectively (Figures 3(a) and 3(b)). The rate of IVTD decline for leaves was consistently lower than stems across years (Figures 3(a) and 3(b)).

There was a significant $(P<0.05)$ variation among GDD within year for SH neutral detergent fiber digestibility ((NDFD; 48 hrs; Table 3)). In 2015, the variation in leaf NDFD was weakly $\left(R^{2}=0.03\right)$ explained by GDD (Figure 3(c)); the variation could be related to factors other than GDD. Leaf and stem NDFD generally decreased with increased GDD with leaf maintaining significantly greater NDFD throughout the growing season (Figures 3(c) and $3(\mathrm{~d})$ ).

The most important factors that determine composition and digestibility of grass are temperature and reproductive development [47]. The increase in temperature accelerates tiller development and increases cell wall concentration [48]. The proportions of cell wall components (hemicellulose, cellulose, and lignin) are negatively correlated with forage digestibility [36]. As crop maturity increases, cell wall constituents increase [49], and a simultaneous increase in lignin decreases digestibility. Among years, leaf IVTD concentrations ranged from 864 to $948 \mathrm{~g} \mathrm{~kg}^{-1} \mathrm{DM}$ and stem IVTD ranged from 463 to $763 \mathrm{~g} \mathrm{~kg}^{-1} \mathrm{DM}$ (Figures 3(a) and 3(b)). Similarly, leaf NDFD ranged from 961 to $972 \mathrm{~g} \mathrm{~kg}^{-1}$ DM and stem NDFD ranged from 931 to $947 \mathrm{~g} \mathrm{~kg}^{-1} \mathrm{DM}$ (Figures 3(c) and 3(d)). In contrast, these digestibility values were greater than the digestibility values of the whole plant SH reported by Lepcha et al. [20] across years and sampling dates.

There are no known studies available in relation to $\mathrm{SH}$ forage digestibility. However, by comparisons, IVTD and NDFD values for SH leaves were greater than that of tall fescue that maintained an IVTD around $806 \mathrm{~g} \mathrm{~kg}^{-1}$ [50] and NDFD of $590 \mathrm{~g} \mathrm{~kg}^{-1}$ NDF during summer months [51]. Alfalfa leaves at mid-flowering stage had IVTD of $762 \mathrm{~g} \mathrm{~kg}^{-1}$ and stem digestibility ranged from 662 to $462 \mathrm{~g} \mathrm{~kg}^{-1}$ DM from upper to lower plant canopy [45]. Although not measured in our study, since digestibility is affected by lignin concentration in the forage fiber, the lower lignin concentration in SH forage leaf fiber [16] would have increased IVTD and NDFD compared with the stem.

Dry matter intake and animal production are associated with feed NDF digestibility [41], and the values for NDFD of different forage types can range from less than $25 \%$ to over $75 \%$ [52]. According to estimations by Oba and Allen [53], every 1 -unit increase in forage NDFD increases $0.17 \mathrm{~kg} \mathrm{~d}^{-1}$ of DM intake, $0.23 \mathrm{~kg} \mathrm{~d}^{-1}$ of milk yield, and $0.25 \mathrm{~kg} \mathrm{~d}^{-1}$ of $4.0 \%$ fat-corrected milk. Although the $\mathrm{SH}$ stem showed greater NDF concentration, this might increase total tract digestibility of NDF as greater NDF concentrations lower DM intake and increase rumen retention time [41]. Feeding both leaf and stem of $\mathrm{SH}$ would provide greater levels of NDFD; however, SH leaves would be a greater quality forage than the stem when digestibility of cool-season forages declines linearly during summer months.

\section{Conclusions}

Forage mass and nutritive value partitioning of $\mathrm{SH}$ leaves and stems varied depending upon summer growing conditions and sampling dates. Forage mass partitioning was primarily affected by the differences in growth stages as a result of differences in GDD. On the other hand, partitioning of forage nutritive traits was affected by increased forage accumulation as influenced by GDD. As crop biomass increased and the leaf-stem ratio decreased, greater proportion of forage mass was consistently partitioned to the stem. As the structural tissues proportion occupies larger portion of stem than leaves, the total fiber (NDF) concentration in stem increases. This in turn resulted in partitioning lower forage nutritive content to the stem than leaves. Although forage mass was consistently partitioned to stem, sunn hemp demonstrated considerable potential for balanced forage mass and nutritive value distribution into the leaf and stem when managed in a low-input system. Although leaf biomass accumulation increased greatly with maturity, leaf nutritive values remained unchanged throughout the summer growing season. While $\mathrm{SH}$ stems accumulate lower $\mathrm{CP}$ and greater fiber concentrations, stem NDFD could add value to cool-season forage-livestock systems during summer. Our results suggested that both the stem and leaf of SH serve as reliable sources of forage and that $\mathrm{SH}$ leaves provide highnutritive value forage throughout the growing season.

Future research should investigate sunn hemp forage intake under both grazing and stored forage feeding systems to validate optimum nutritive values. Research should also include optimization of seeding rates, date of planting, fertilization, delayed harvests, and cultivars to further determine the effect of these factors on forage mass and nutritive value partitioning into plant components.

\section{Data Availability}

The Excel file data used to support the findings of this study are available from the corresponding author upon request.

\section{Conflicts of Interest}

The authors declare that there are no conflicts of interest regarding the publication of this paper.

\section{Acknowledgments}

This research was funded by the Division of Plant Sciences, University of Missouri, Columbia, MO, 65211, and United States Department of Agriculture-National Institute of Food and Agriculture Multistate Research Project (USDA-NIFA NC-1119), USA.

\section{References}

[1] R. W. Hintz and K. A. Albrecht, "Dry matter partitioning and forage nutritive value of soybean plant components," Agronomy Journal, vol. 86, no. 1, pp. 59-62, 1994.

[2] A. J. Smart, W. H. Schacht, J. D. Volesky, and L. E. Moser, "Seasonal changes in dry matter partitioning, yield, and crude 
protein of intermediate wheatgrass and smooth bromegrass," Agronomy Journal, vol. 98, no. 4, pp. 986-991, 2006.

[3] A. G. Matches, "Management," in Tall Fescue, R. C. Buckner and L. P. Bush, Eds., vol. 20, pp. 171-199, ASA, CSSSA, and SSSA, Madison, WI, USA, 1979.

[4] S. S. Bughrara, D. A. Sleper, and G. F. Krause, "Genetic variation in tall fescue digestibility estimated using a prepared cellulase solution," Crop Science, vol. 31, no. 4, pp. 883-889, 1991.

[5] J. C. Burns, "Utilization, quality, and anti-quality factors-nutritive value," in Tall Fescue for the Twenty-First Century Agronomy Monograph, H. A. Fribourg, D. B. Hannaway, and C. P. West, Eds., vol. 53, pp. 159-202, ASA, CSSA, and SSSA, Madison, WI, USA, 2009.

[6] C. G. Cook and G. A. White, "Crotalaria juncea: a potential multi-purpose fiber crop," in Progress in New Crops ASHS Press, J. Janick, Ed., pp. 389-394, Arlington, VA, USA, 1996.

[7] P. P. Rotar and R. J. Joy, Tropic Sun sunn hemp, Crotalaria juncea L, Vol. 36, Research Extension University of Hawaii, Honolulu, HI, USA, 1983.

[8] B. G. Cook, B. C. Pengelly, S. D. Brown et al., "Tropical Forages: An Alternative Selection Tool”, Web Tool. CSIRO, DPI\&F(Qld), CIAT and ILRI, Brisbane, Australia, 2005.

[9] D. Treadwell, C. Chase, A. Cho, M. Alligood, and J. Elsakr, "Potential for sunn hemp (Crotalaria juncea) to utilize soil potassium," Proceedings of the Florida State Horticultural Society, vol. 122, pp. 243-246, 2009.

[10] National Research Council, "Sunn hemp," in Advisory Committee on Technology Innovation, Tropical Legumes: Resources for the Future, pp. 272-278, The National Academy of Science Press, Washington, DC, USA, 1979.

[11] J. M. Burke, J. A. Mosjidis, J. E. Miller, and P. Casey, "Sunn hemp with chicory or pearl millet to minimize gastrointestinal nematode infection in weaned goats," in Abstracts, pp. 17-18, American Society of Animal Science Southern Section Meeting, Corpus Christi, TX, USA, 2011.

[12] H. H. Schomberg, N. L. Martini, J. C. Diaz-Perez, S. C. Phatak, K. S. Balkcom, and H. L. Bhardwaj, "Potential for using sunn hemp as a source of biomass and nitrogen for the Piedmont and Coastal Plain Regions of the southeastern USA," Agronomy Journal, vol. 99, no. 6, pp. 1448-1457, 2007.

[13] A. A. Abdul-baki, H. H. Bryan, G. M. Zinati, W. Klassen, M. Codallo, and N. Heckert, "Biomass yield and flower production in sunn hemp: effect of cutting the main stem," Journal of Vegetable Crop Production, vol. 7, no. 1, pp. 83-104, 2001.

[14] A. H. Cho, C. A. Chase, D. D. Treadwell, R. L. Koenig, J. B. Morris, and J. P. Morales-Payan, "Apical dominance and planting density effects on weed suppression by sunn hemp (Crotalaria juncea L.)," HortScience, vol. 50, no. 2, pp. 263-267, 2015.

[15] R. C. Katiyar and S. K. Ranjhan, "Chemical composition and nutritive value of sun hemp (Crotalaria juncea L.) as a fodder for livestock," Indian Veterinary Journal, vol. 46, pp. 161-164, 1969.

[16] Z. Mansoer, D. W. Reeves, and C. W. Wood, "Suitability of sunn hemp as an alternative late-summer legume cover crop," Soil Science Society of America Journal, vol. 61, no. 1, pp. 246-253, 1997.

[17] National Research Council, Nutrient Requirements of Dairy Cattle, National Academy Press, Washington, DC, USA, 6th edition, 1989.
[18] K. B. Cantrell, P. J. Bauer, and K. S. Ro, "Utilization of summer legumes as bioenergy feedstocks," Biomass and Bioenergy, vol. 34, no. 12, pp. 1961-1967, 2010.

[19] N. Balaraman and R. Vankaterkrishman, "Nutritive value of sunnhemp (Crotalaria juncea L.) hay for Sheep," Indian Veterinary Journal, vol. 51, no. 5, pp. 337-341, 1974.

[20] I. Lepcha, H. D. Naumann, F. B. Fritschi, and R. L. Kallenbach, "Herbage accumulation, nutritive value, and regrowth potential of sunn hemp at different harvest regimens and maturity," Crop Science, vol. 59, no. 1, pp. 413-421, 2019.

[21] USDA-NRCS, Soil Survey of Boone County, USDA-NRCS, Missouri, MI, USA, 1998.

[22] K. S. Balkcom, J. M. Massey, J. A. Mosjidis, A. J. Price, and S. F. Enloe, "Planting date and seeding rate effects on sunn hemp biomass and nitrogen production for a winter cover crop," International Journal of Agronomy, vol. 2011, Article ID 237510, 8 pages, 2011.

[23] D. Undersander, D. R. Mertens, and N. Thiex, "Forage Analyses Procedures, National Forage Testing Association, Omaha, NE, USA, 1993.

[24] D. R. Mertens, "Do we need to consider NDF digestibility in the formulation of ruminant diets?" in Proceedings of the 27th Western Nutrition Conference, Western Nutrition Conference Committee, pp. 75-98, Winnipeg, Manitoba, CA, USA, September, 2006.

[25] SAS Institute, “The SAS System for Windows," Version 9.4, SAS Institute Inc., Cary, NC, USA, 2013.

[26] G. Lemaire, M. Khaity, B. Onillon, J. M. Allirand, M. Chartier, and G. Gosse, "Dynamics of accumulation and partitioning of $\mathrm{N}$ in leaves, stems and roots of Lucerne (Medicago sativa L.) in a dense canopy," Annals of Botany, vol. 70, no. 5, pp. 429-435, 1992.

[27] A. J. Marshall, R. N. Gallaher, K. H. Wang, and R. McSorley, "Partitioning of dry matter and minerals in sunn hemp," in Making Conservation Tillage Conventional: Building a Future on 25 Years of Research, Proceedings of 25th Annual Southern Conservation Tillage Conference for Sustainable Agriculture, E. van Santen, Ed., , Auburn, AL, USA, June 2002.

[28] J. D. Mosjidis, K. S. Balkcom, J. M. Burke, P. Casey, J. B. Hess, and G. Wehtje, Production of the Sunn Hemp Cultivars; "AU Golden" and "AU Durbin", Technical Report 328, pp. 1-7, Auburn University, Auburn, Alabama, 2013.

[29] S. Saha, M. Saha, A. R. Saha et al., "Interaction effect of potassium and sulfur fertilization on productivity and mineral nutrition of sunn hemp," Journal of Plant Nutrition, vol. 36, no. 8, pp. 1191-1200, 2012.

[30] H. L. Bhardwaj, C. L. Webber III, and G. S. Sakamoto, "Cultivation of kenaf and sunn hemp in the mid-Atlantic United States," Industrial Crops and Products, vol. 22, no. 2, pp. 151-155, 2005.

[31] K. J. Shinners, M. E. Herzmann, B. N. Binversie, and M. F. Digman, "Harvest fractionation of alfalfa," Transactions of the ASABE, vol. 50, no. 3, pp. 713-718, 2007.

[32] R. A. Halim, D. R. Buxton, M. J. Hattendorf, and R. E. Carlson, "Water-stress effects on alfalfa forage quality after adjustment for maturity differences," Agronomy Journal, vol. 81, no. 2, pp. 189-194, 1989.

[33] G. Bélanger and J. E. Richards, "Dynamics of biomass and N accumulation of alfalfa under three $\mathrm{N}$ fertilization rates," Plant and Soil, vol. 219, no. 1/2, pp. 177-185, 2000.

[34] F. Gastal and G. Lemaire, "N uptake and distribution in crops: an agronomical and ecophysiological perspective," Journal of Experimental Botany, vol. 53, no. 370, pp. 789-799, 2002. 
[35] A. M. Grev, M. S. Wells, D. A. Samac, K. L. Martinson, and C. C. Sheaffer, "Forage accumulation and nutritive value of reduced lignin and reference alfalfa cultivars," Agronomy Journal, vol. 109, no. 6, pp. 2749-2761, 2017.

[36] D. R. Buxton, "Quality-related characteristics of forages as influenced by plant environment and agronomic factors," Animal Feed Science and Technology, vol. 59, no. 1-3, pp. 37-49, 1996.

[37] National Research Council, "Nutrient requirements of beef cattle," in Subcommittee on Beef Cattle Nutrition, pp. 102-112, National Academy Press, Washington, DC, USA, 7th edition, 2000.

[38] Z. Solati, U. Jørgensen, J. Eriksen, and K. Søegaard, "Estimation of extractable protein in botanical fractions of legume and grass species," Grass and Forage Science, vol. 73, no. 2, pp. 572-581, 2017.

[39] J. Hakl, P. Fuksa, J. Šantrůček, and J. Santrucek, "Differences in the crude protein fractions of Lucerne leaves and stems under different stand structures," Grass and Forage Science, vol. 71, no. 3, pp. 413-423, 2015.

[40] D. R. Buxton and D. D. Redfearn, "Plant limitations to fiber digestion and utilization," Journal of Nutrition, vol. 127, no. 5, pp. 814S-818S, 1997.

[41] C. Kendall, C. Leonardi, P. C. Hoffman, and D. K. Combs, "Intake and milk production of cows fed diets that differed in dietary neutral detergent fiber and neutral detergent fiber digestibility," Journal of Dairy Science, vol. 92, no. 1, pp. 313-323, 2009.

[42] M. S. Allen, "Fiber requirements for dairy cattle? How low can you go?" in Proceedings of California Animal Nutrition Conference, pp. 12-18, University of California, Davis, CA, USA, 1996.

[43] D. R. Mertens, "Regulation of forage intake," in Forage Quality, Evaluation, and Utilization, G. C. Fahey, Ed., pp. 450-493, ASA ASA, CSSA, and SSSA, Madison, WI, USA, 1994.

[44] D. R. Buxton and J. S. Hornstein, "Cell-wall concentration and components in stratified canopies of alfalfa, birdsfoot trefoil, and red clover 1," Crop Science, vol. 26, no. 1, pp. 180-184, 1986.

[45] D. R. Buxton, J. S. Hornstein, W. F. Wedin, and G. C. Marten, "Forage quality in stratified canopies of alfalfa, birdsfoot trefoil, and red Clover1," Crop Science, vol. 25, no. 2, pp. 273-279, 1985.

[46] D. A. Sleper and C. P. West, "Tall fescue," in Cool-season Forage Grasses Agronomy Monograph, L. E. Moser, D. R. Buxton, and M. D. Casler, Eds., vol. 34, pp. 471-502, ASA, CSSA, and SSSA, Madison, WI, USA, 1996.

[47] D. R. Buxton and S. L. Fales, "Plant environment and quality," in Forage Quality, Evaluation and Utilization, G. C. Fahey, Ed., pp. 155-159, ASA, CSSA, and SSSA, Madison, WI, USA, 1994.

[48] J. C. G. Groot, E. A. Lantinga, J. H. Neuteboom, and B. Deinum, "Analysis of the temperature effect on the components of plant digestibility in two populations of perennial ryegrass," Journal of the Science of Food and Agriculture, vol. 83, no. 4, pp. 320-329, 2003.

[49] C. J. Nelson and L. E. Moser, "Plant factors affecting forage quality," in Forage Quality, Evaluation and Utilization, G. C. Fahey, Ed., pp. 115-154, ASA, CSSA, and SSSA, Madison, WI, USA, 1994.

[50] E. D. Billman, B. M. Goff, B. S. Baldwin, K. Prince, and T. D. Phillips, "Effects of vegetative cool-season grasses on forage removal by dairy heifers," Agronomy Journal, vol. 109, no. 4, pp. 1540-1550, 2017.

[51] K. B. Jensen, J. G. Robins, C. Rigby, and B. L. Waldron, "Comparative trends in forage nutritional quality across the growing season in thirteen grasses," Canadian Journal of Plant Science, vol. 97, no. 1, pp. 72-82, 2017.

[52] National Research Council, Nutrient Requirements of Dairy Cattle, National Academy of Science, Washington, DC, USA, 7th edition, 2001.

[53] M. Oba and M. S. Allen, "Evaluation of the importance of the digestibility of neutral detergent fiber from forage: effects on dry matter intake and milk yield of dairy cows," Journal of Dairy Science, vol. 82, no. 3, pp. 589-596, 1999. 